\title{
Sodium butyrate and monensin supplementation to postweaning heifer diets: Effects on growth performance, nutrient digestibility, and health
}

\author{
T. C. Stahl, ${ }^{1} \odot$ E. Hatungimana, ${ }^{1}$ K. D. Klanderman, ${ }^{2} \odot$ S. C. Moreland, ${ }^{2}$ and P. S. Erickson ${ }^{1 *} \odot$ \\ ${ }^{1}$ Department of Agriculture, Nutrition, and Food Systems, University of New Hampshire, Durham, 03824 \\ ${ }^{2}$ Adisseo USA Inc., Alpharetta, GA
}

\begin{abstract}
The objective of this study was to evaluate growth and performance of postweaning heifers supplemented with monensin $(\mathrm{MON})$, sodium butyrate $(\mathrm{SB})$, or the combination of MON and SB (MSB) compared with heifers not receiving these feed additives. Forty Holstein heifers [mean age $84.2 \pm 1.2 \mathrm{~d}$; body weight (BW) $99.8 \pm 10.8 \mathrm{~kg}($ mean $\pm \mathrm{SD})]$ were housed in a freestall barn, blocked by birth date, and randomly assigned to 1 of 4 treatments in a randomized complete block design. Treatments were (1) $100 \mathrm{~g}$ of soybean meal carrier (control; CON); (2) $0.75 \mathrm{~g}$ of $\mathrm{SB} / \mathrm{kg}$ of $\mathrm{BW}+$ carrier (SB); (3) $1 \mathrm{mg}$ of $\mathrm{MON} / \mathrm{kg}$ of $\mathrm{BW}+$ carrier $(\mathrm{MON}) ;(4) 1 \mathrm{mg}$ of $\mathrm{MON} / \mathrm{kg}$ of BW $+0.75 \mathrm{~g}$ of SB $/ \mathrm{kg}$ of BW (MSB). Data were analyzed using single degree of freedom contrasts evaluating $\mathrm{CON}$ versus additives (ADD), SB versus MON, and $\mathrm{SB}$ and $\mathrm{MON}$ versus MSB. Treatments were hand-mixed daily. Feed and orts were measured daily and frozen at $-20^{\circ} \mathrm{C}$. Orts samples were subsampled for dry matter (DM) determination, and total mixed ration samples were taken weekly and composited monthly for DM and nutrient analysis. Initial BW, heart and paunch girths, body length, blood samples, and fecal coccidia counts were measured before the start and weekly during the 12-wk trial. Blood samples were analyzed for glucose, plasma urea nitrogen (PUN), and ketone concentrations. Apparent totaltract nutrient digestibility was determined from d 21 to 27 and from d 63 to 69 using acid detergent insoluble ash as a marker. Daily dry matter intake (DMI) and metabolizable energy intake were increased in ADD compared with $\mathrm{CON}$, and average $\mathrm{BW}$, final $\mathrm{BW}$, and heart girth tended to increase. Whereas MSB tended to be greater than SB and MON for heart girth, feed efficiency was greater with MON compared with SB. Compared with CON, ADD decreased coccidia counts.
\end{abstract}

Received March 24, 2020.

Accepted July 1, 2020.

*Corresponding author: peter.erickson@unh.edu
No effect of treatment on PUN was detected. Monensin and SB tended to have greater plasma glucose than MSB did. Average blood ketone concentrations were greater with $\mathrm{ADD}$ versus $\mathrm{CON}$, in $\mathrm{SB}$ versus $\mathrm{MON}$, and in MSB versus SB and MON. During the wk-3 digestibility phase, DMI tended to be greater in heifers fed SB versus MON, as well as in heifers fed MSB versus SB and MON. Digestibility of nutrients were similar, except that starch digestibility was increased in heifers fed MSB versus SB and MON. During the wk-9 digestibility phase, DMI and digestibility of nutrients were similar, except NDF, which tended to be greater in CON than in ADD. Overall, ADD resulted in positive growth and reduced coccidia compared with CON.

Key words: sodium butyrate, monensin, postweaned heifer, growth, coccidia

\section{INTRODUCTION}

Raising replacement heifers is one of the largest expenses on the farm (Gabler et al., 2000; Heinrichs et al., 2013). It is important to closely manage youngstock, along with providing adequate nutrition, to ensure that such animals will reach developmental maturity. Diet manipulation, such as changing VFA proportions in the rumen, can affect performance. For example, feeding ionophores will reduce acetate and butyrate production, thus increasing propionate production (Russell and Strobel, 1988; McGuffey, 2017). When adding ionophores to the diet of youngstock, an increase in feed efficiency (FE) results in increased nutrient absorption (Rouquette et al., 1980; Baile et al., 1982). Ionophores have reduced coccidian oocyst shedding in the feces, leading to an improvement in the health of the animal (Quigley et al., 1997). However, in 2006 the European Union put a ban on antibiotic-like growth promoters (European Commission, 2005). An additive that has been shown to cause growth promotion that could replace ionophores is sodium butyrate (SB; Górka et al., 2018c; Rice et al., 2019).

Butyrate is utilized by ruminal epithelial tissues to increase proliferation of rumen papillae (Górka et al., 
2011a,b). Increasing dimensions and density of papillae will result in an increase in the absorptive capabilities of the rumen (Górka et al., 2011a,b, 2018c). With absorptive capacity increased, heifers can utilize more nutrients for growth. In addition to ruminal tissue, small intestine (SI) epithelial tissue can be enhanced by SB supplementation (Guilloteau et al., 2009; Górka et al., 2014). Inclusion of microencapsulated SB in the starter grain increased the mitotic and decreased the apoptotic indices of SI enterocytes (Górka et al., 2014). Microencapsulation allows SB to bypass the rumen and be utilized in the SI. This suggests that SB can maintain the growth of SI epithelial cells, which aids in the absorptive function of the lower gastrointestinal tract. Sodium butyrate has also been shown to increase the secretion of pancreatic juices that aid in the digestion of feeds (Guilloteau et al., 2010b).

With these effects on intestinal development and enhanced absorptive capacity, the improved growth performance that has been seen in younger animals supplemented SB (Górka et al., 2018a) are still present in older heifers. Rice et al. (2019) investigated SB on growth and health performance of heifers after weaning and found increased average BW and a tendency toward greater final $\mathrm{BW}$ and $\mathrm{FE}$ as $\mathrm{SB}$ increased from 0 to $0.75 \mathrm{~g} / \mathrm{kg}$, along with a reduction in coccidian oocysts at $0.25 \mathrm{~g}$ of $\mathrm{SB} / \mathrm{kg}$.

The objective of this study was to evaluate growth, coccidia counts, and apparent total-tract nutrient digestibility of postweaning heifers supplemented with monensin (MON), SB, or the combination of MON and SB (MSB), compared with heifers not receiving these feed additives. We hypothesized that feeding either MON or SB would increase BW gain, reduce coccidia levels, and improve apparent total-tract nutrient digestibility in dairy heifers.

\section{MATERIALS AND METHODS}

\section{Experimental Design and Treatments}

This experiment was reviewed and approved by the University of New Hampshire (Durham) Animal Care and Use Committee (Protocol No. 170903). The experiment was conducted from February 2018 to March 2019.

Forty Holstein heifers with a mean age of $84.2 \pm 1.2$ $\mathrm{d}$ [mean \pm standard deviation (SD)] and average initial $\mathrm{BW}$ of $99.8 \pm 10.8 \mathrm{~kg}$ (mean $\pm \mathrm{SD}$ ) were blocked by date of birth and randomly assigned to 1 of 4 treatments in a randomized complete block design. Heifers were not blocked by initial weight, and differences observed in initial weight were due to randomization. Treatments were (1) $100 \mathrm{~g}$ of soybean meal carrier (control; CON); (2) $0.75 \mathrm{~g}$ of $\mathrm{SB} / \mathrm{kg}$ of $\mathrm{BW}+$ carrier (SB); (3) $1 \mathrm{mg}$ of monensin $/ \mathrm{kg}$ of BW + carrier (MON); (4) $1 \mathrm{mg}$ of $\mathrm{MON} / \mathrm{kg}$ of $\mathrm{BW}+0.75 \mathrm{~g}$ of SB per $\mathrm{kg}$ of BW (MSB). The SB dose was the same as the dose that resulted in the greatest FE response in a previous study (Rice et al., 2019). The MON dose was in the range for the dose required for the prevention and control of coccidiosis (Code of Federal Regulations, 2019). All heifers were given $100 \mathrm{~g}$ of carrier (soybean meal) per day, and their respective treatments were adjusted weekly according to individual BW. Sodium butyrate provided was unprotected and was a $90 \%$ SB product ( $68 \%$ butyric acid, $22 \% \mathrm{Na}^{+}$, and $\sim 10 \%$ maltodextrin; Ultramix $\mathrm{GF}$, Nutriad Inc. USA, Hampshire, IL). Maltodextrin was added by the manufacturer to improve granulation of SB.

\section{Management and Feeding}

Heifers were group-housed in a naturally ventilated freestall barn with mattresses bedded with kiln-dried sawdust. Two adjacent pens (pen 1: $5.46 \times 4.75 \mathrm{~m}$; pen 2: $5.54 \times 4.88 \mathrm{~m}$ ) were used, pen 1 having the capacity to hold 6 heifers, and pen 2 having the capacity to hold 8 heifers. Heifers had unlimited access to water through automatically refilling water troughs and no competition for stall space. Each stall in pen 1 had the following dimensions: $1.14 \mathrm{~m}$ length of lying space from brisket board $(0.27 \mathrm{~m}$ width brisket board $)$ to end of stall, $0.77 \mathrm{~m}$ width between stall dividers, $0.74 \mathrm{~m}$ height from mattress to neck rail, and $0.20 \mathrm{~m}$ curb height. Each stall in pen 2 had the following dimensions: $1.19 \mathrm{~m}$ length of lying space from brisket board $(0.19 \mathrm{~m}$ width brisket board) to end of stall, $0.71 \mathrm{~m}$ width between stall dividers, $0.74 \mathrm{~m}$ height from mattress to neck rail, and $0.20 \mathrm{~m}$ curb height. Heifers entered pen 1 to train to use Calan doors (American Calan Inc., Northwood, $\mathrm{NH}$ ) at 12 wk of age. Heifers began the study on the first Tuesday of the $13 \mathrm{wk}$ of age and remained on the study for 12 wk. After 7 heifers were on the experiment, the largest heifers were moved into pen 2 as needed. The minimum number of heifers in any pen was 2 .

Heifers were individually fed a TMR (Table 1) at approximately $1100 \mathrm{~h}$ daily in individual feed tubs (pen 1: $0.90 \mathrm{~m}$ length $\times 0.48 \mathrm{~m}$ width; pen $2: 0.97 \mathrm{~m}$ length $\times 0.66 \mathrm{~m}$ width) to allow for daily feed intake measurements. Feed was mixed and distributed using a motorized feeding vehicle (Super Data Ranger; American Calan Inc.). The ration was fed to obtain feed refusals amounting to $10 \%$ or less, and the amount fed was adjusted daily according to individual intakes. Treatments were hand-mixed into each heifer's feed. 
Table 1. Ingredient composition ( $\%$ of $\mathrm{DM} \pm \mathrm{SD}$ ) of experimental diet

\begin{tabular}{|c|c|}
\hline Item & DM, $\%$ \\
\hline Hay crop silage & $37.46 \pm 1.83$ \\
\hline Corn silage & $33.87 \pm 3.88$ \\
\hline Energy mix $^{1}$ & $12.53 \pm 4.80$ \\
\hline Soy/urea mix $^{2}$ & $11.89 \pm 2.54$ \\
\hline Provail $^{3}$ & $2.26 \pm 0.009$ \\
\hline Mineral/vitamin $\operatorname{mix}^{4}$ & $1.99 \pm 0.005$ \\
\hline
\end{tabular}

${ }^{1}$ Energy mix contained 5\% molasses, $45.80 \%$ corn meal, $15.20 \%$ steamflaked corn, and $34 \%$ whole beet pulp.

${ }^{2}$ Soy/urea mix contained $7.28 \%$ distillers grain, $69.14 \%$ soybean meal, $21.83 \%$ canola meal, and $1.75 \%$ urea.

${ }^{3}$ RUP mix containing $97.1 \%$ blood meal and $2.9 \%$ Smartamine-M (Adisseo, Antony, France).

${ }^{4}$ Mineral/vitamin mix contained $19.05 \% \mathrm{Ca} ; 6.01 \% \mathrm{P} ; 3.51 \% \mathrm{Mg}$; $20.00 \%$ salt: $7.80 \% \mathrm{Na}: 0.29 \%$ Fe; $0.26 \%$ Zn; $0.26 \% \mathrm{Mn} ; 12.3 \% \mathrm{Cl}$ $602.00 \mathrm{mg} / \mathrm{kg} \mathrm{Cu} ; 15.00 \mathrm{mg} / \mathrm{kg} \mathrm{Co} ; 25.09 \mathrm{mg} / \mathrm{kg} \mathrm{Se} ; 15.00 \mathrm{mg} / \mathrm{kg} \mathrm{I}$; $267,800 \mathrm{IU} / \mathrm{kg}$ vitamin $\mathrm{A} ; 111,071 \mathrm{IU} / \mathrm{kg}$ vitamin $\mathrm{D}$; and 2,207 IU/ $\mathrm{kg}$ vitamin E.

\section{Feed Analysis}

Both orts and TMR were recorded for the determination of DMI. Samples of TMR were taken once weekly on Mondays to get a representative sample of the diet fed to the animals, and orts were obtained daily from each heifer at $1030 \mathrm{~h}$. Both TMR and orts were frozen at $-20^{\circ} \mathrm{C}$ for future analysis. Samples were thawed and placed in a forced hot air convection oven (Binder, Bohemia, NY) to dry at $55^{\circ} \mathrm{C}$ for $48 \mathrm{~h}$ to determine $\mathrm{DM}$ concentration.

Samples were ground through a 1-mm screen using a Wiley mill (Thomas Scientific, Swedesboro, NJ) and sent to a commercial laboratory for nutrient analysis (Rock River Laboratories, Watertown, WI). Feed samples were analyzed for ADF (method 5 in an Ankom Fiber Analyzer A2000; Ankom Technology, Macedon, NY; method 973.18, AOAC International, 1998), NDF (method 6 in an Ankom Fiber Analyzer A2000 with Q-amylase and sodium sulfite; Ankom Technology; solutions as in Van Soest et al., 1991), starch (YSI 2700 SELECT Biochemistry Analyzer; YSI Inc. Life Sciences, Yellow Springs, OH), crude fat (ether extraction; method 2003.05, AOAC International, 2006), ash (method 942.05, AOAC International, 2006), and CP (method 990.03, AOAC International, 2006).

\section{Animal Measurements}

Each heifer was weighed and skeletal measurements were taken before feeding and receiving treatments every Tuesday at $0800 \mathrm{~h}$ throughout the $12 \mathrm{wk}$ on study. Heifers were measured for body length, heart girth, and paunch girth. All length and girth measurements were determined using a weigh tape. Heifers were weighed on a portable scale system (EziWeigh5i, Tru-Test, Uniontown, PA).

\section{Blood Sampling and Analysis}

Blood samples were obtained from the jugular vein using a 20-gauge needle before the administration of treatments. Once each heifer was assigned to her respective treatment, blood samples were collected every Tuesday at $0800 \mathrm{~h}$ for the duration of the study. Samples were collected in two $10-\mathrm{mL}$ evacuated tubes, the first containing EDTA anticoagulant and the second without anticoagulant (Monoject, Covidien Ilc., Mansfield, MA). Blood ketone concentrations were obtained using a hand-held electronic blood glucose and ketone monitoring device (Nova Max Plus, Nova Biomedical, Waltham, MA; Deelen et al., 2016). A whole-blood sample, not containing EDTA, was transferred to the sensor of the test strip using a disposable pipette.

Samples with EDTA were placed on ice until they were centrifuged at $1,278 \times g$ at $4^{\circ} \mathrm{C}$ for $20 \mathrm{~min}(5430 \mathrm{R}$, Eppendorf, Hamburg, Germany). Plasma was stored in 2 aliquots and frozen at $-20^{\circ} \mathrm{C}$ until further analysis of plasma urea nitrogen (PUN) and glucose. Urea concentrations were measured in duplicate using the diacetyl-monoxime method and measured colorimetrically using a UV-visible spectrophotometer (Beckman Coulter Inc., Brea, CA) set at a wavelength of $540 \mathrm{~nm}$. Plasma glucose concentrations were measured in duplicate via Wako Autokit for Glucose (Wako Diagnostics, Mountain View, CA) and read on a UV-visible spectrophotometer at a wavelength of $505 \mathrm{~nm}$.

\section{Digestibility Measurements}

Each of the 40 heifers underwent apparent total-tract nutrient digestibility phases at $21 \mathrm{~d}$ on study until $27 \mathrm{~d}$, and again at $63 \mathrm{~d}$ until $69 \mathrm{~d}$. Total mixed ration samples were taken d 1 through d 5 , and individual ort samples were collected d 2 through d 6 . Orts and TMR samples were then frozen at $-20^{\circ} \mathrm{C}$ for future analysis. Samples were thawed and placed in a forced hot air convection oven to dry at $55^{\circ} \mathrm{C}$ for $48 \mathrm{~h}$ to determine DMI. Both orts and TMR samples were then composited over the sampling days.

Fecal grab samples were collected on d 4 through d 7 every $6 \mathrm{~h}$, to represent a 24-h period of each digestibility period, by stimulating defecation or collecting feces directly from the rectum. Samples over the 3-d period were combined to obtain a single composite and frozen at $-20^{\circ} \mathrm{C}$. Fecal samples were thawed at room temperature and emptied into aluminum trays to be dried in a forced-air oven at $55^{\circ} \mathrm{C}$ for approximately $72 \mathrm{~h}$ until completely dried. The dried TMR, orts, 
and fecal samples were ground through a Wiley mill 1-mm screen (Thomas Scientific). Ground samples were sent to Rock River Laboratories (Watertown, WI) for analysis. Feed, orts, and fecal samples were analyzed for acid detergent insoluble ash (ADIA) according to Van Keulen and Young (1977) and for CP, NDF, ADF, starch, ash, and fat as described for feed samples.

The equation used to estimate digestibility was as follows:

$$
\begin{aligned}
& 100-[100 \times(\% \text { ADIA in DM consumed } / \\
& \% \text { ADIA in feces }) \times(\% \text { nutrient in feces } / \\
& \text { nutrient consumed DM })]
\end{aligned}
$$

\section{Coccidia Count}

Fecal samples were obtained from each heifer before the start of treatment, and then weekly from each heifer on Tuesday at $0800 \mathrm{~h}$. Samples were collected by stimulating defecation or collecting feces directly from the rectum. Samples were analyzed for coccidian oocysts following the modified Wisconsin sugar fecal worm egg flotation method (Bliss and Kvasnicka, 1997). Incidence rate of coccidia was calculated based on whether heifers had coccidian oocysts present in their fecal samples. Heifers were observed daily for indications of illness.

\section{Statistical Analysis}

Pre-planned contrasts were used to determine whether any benefits were to be gained by feeding feed additives (SB, MON, and MSB) compared with CON, and to detect any differences among additives. Initial BW, skeletal measurements, serum glucose, PUN, ketones, coccidia counts, and presence of coccidia served as covariates for their respective variables of interest. Weekly DMI, ADG, ME intake, FE (ADG/DMI), $\mathrm{BW}$, skeletal measurements, average coccidia counts, incidence rate of coccidia, and blood metabolites (whole-blood ketones, plasma glucose, and PUN) were analyzed as a randomized complete block design with repeated measures, using the MIXED procedure of SAS version 9.4 (SAS Institute Inc., Cary, NC) according to the following model:

$$
\mathrm{Y}_{\mathrm{ijkl}}=\mu+\mathrm{B}_{\mathrm{i}}+\operatorname{Trt}_{\mathrm{j}}+\mathrm{W}_{\mathrm{k}}+\beta \mathrm{X}_{\mathrm{ij}}+\operatorname{Trt}_{\mathrm{jk}}+\mathrm{E}_{\mathrm{ijkl}},
$$

where $Y_{\mathrm{ijkl}}=$ the dependent variable; $\mu=$ the overall mean; $B_{i}=$ the random effect of block $\mathrm{i}(\mathrm{i}=1, \ldots$ ,10); $\operatorname{Trt}_{j}=$ the fixed effect of the jth treatment $[\mathrm{j}=$ CON, $0.75 \mathrm{~g} / \mathrm{kg}$ of $\mathrm{SB}, 1 \mathrm{mg} / \mathrm{kg}$ of MON, or combination (MSB)]; $\mathrm{W}_{\mathrm{k}}=$ the fixed effect of the kth week on study $(\mathrm{k}=1-12) ; \beta=$ the regression (covariate coefficient); $\mathrm{X}_{\mathrm{ij}}=$ the covariate measurement; $\operatorname{TrtW}_{\mathrm{jk}}$ $=$ the fixed interaction between the jth treatment and the kth week; and $E_{\mathrm{ijkl}}=$ the residual error.

In this model, the random effect of heifer within block subclass was used as the error term for the effect of treatment. The residual errors are errors within heifer across time and represent errors for repeated measurements in the experimental units (heifers). For most variables analyzed, first-order autoregressive resulted in the smallest Bayesian information criteria of the 5 covariate structures tested: first-order autoregressive, Toeplitz, compound symmetry, variance components, and unstructured. All variables, except length gain, paunch girth, paunch girth gain, BW, and average coccidia, were modeled using a first-order autoregressive covariance spatial structure. Paunch girth, paunch girth gain, and average BW were modeled using a Toeplitz covariance spatial structure, as it resulted in the smallest Bayesian information criterion. Body length gain was modeled using compound symmetry covariance spatial structure, as it resulted in the smallest Bayesian information criterion. Average coccidia count was modeled using an unstructured covariance spatial structure, as it resulted in the smallest Bayesian information criterion. Degrees of freedom (df) were calculated using the Kenward-Roger approximation option of the MIXED procedure of SAS. Covariate $P$-values for heart girth gain, coccidia count, average plasma glucose concentration, and ADG were $>0.25$; therefore, they were removed from the model. Single df contrasts for $\mathrm{CON}$ versus additive (ADD), SB versus $\mathrm{MON}$, and ADD versus MSB (single additives vs. MSB) effects were determined for all variables.

Paunch girth, heart girth, and body length were analyzed as a randomized complete block design using the MIXED procedure of SAS according to the following model:

$$
Y_{i j}=\mu+B_{i}+\operatorname{Trt}_{j}+\beta X_{i j}+E_{i j},
$$

where $\mathrm{Y}_{\mathrm{ij}}=$ the dependent variable; $\mu=$ the overall mean; $\mathrm{B}_{\mathrm{i}}=$ the random effect of block $\mathrm{i}(\mathrm{i}=1, \ldots, 10)$; $\mathrm{Trt}_{\mathrm{j}}=$ the fixed effect of the jth treatment $[\mathrm{j}=\mathrm{CON}$, $0.75 \mathrm{~g} / \mathrm{kg}$ of $\mathrm{SB}, 1 \mathrm{mg} / \mathrm{kg}$ of $\mathrm{MON}$, or combination (MSB)]; $\beta=$ the regression (covariate coefficient); $\mathrm{X}_{\mathrm{ij}}$ $=$ the covariate measurement; and $\mathrm{E}_{\mathrm{ijk} \mathrm{l}}=$ the residual error.

Degrees of freedom were calculated using the Kenward-Roger approximation option of the MIXED procedure. Single df contrasts for CON versus ADD, $\mathrm{SB}$ versus MON, and ADD versus MSB effects were determined. 
Table 2. Nutrient analysis (\% of $\mathrm{DM} \pm \mathrm{SD}$ ) of experimental diet

\begin{tabular}{lc}
\hline Item & DM, $\%$ \\
\hline CP & $15.73 \pm 1.43$ \\
ADF & $27.83 \pm 3.04$ \\
NDF & $42.92 \pm 3.25$ \\
Starch & $14.39 \pm 2.06$ \\
NFC $^{1}$ & $32.48 \pm 3.33$ \\
Fat & $2.71 \pm 0.46$ \\
Ash & $7.88 \pm 0.40$ \\
ME $^{2}$ Mcal & $2.51 \pm 0.02$
\end{tabular}

${ }^{1} \mathrm{NFC}=100-[\mathrm{CP} \%+(\mathrm{NDF} \%-$ neutral detergent insoluble crude protein $\%)+$ fat $\%+\operatorname{ash} \%]$.

${ }^{2}$ Estimated from NRC (2001).

Apparent total-tract nutrient digestibility, initial measurements, and overall skeletal measurement gains were analyzed as a randomized complete block design using the MIXED procedure of SAS according to the following model:

$$
\mathrm{Y}_{\mathrm{ij}}=\mu+\mathrm{B}_{\mathrm{i}}+\operatorname{Trt}_{\mathrm{j}}+\mathrm{E}_{\mathrm{ij}}
$$

where $\mathrm{Y}_{\mathrm{ij}}=$ the dependent variable; $\mu=$ the overall mean; $\mathrm{B}_{\mathrm{i}}=$ the random effect of block $\mathrm{i}(\mathrm{i}=1, \ldots, 10)$; $\operatorname{Trt}_{\mathrm{j}}=$ the fixed effect of the $\mathrm{jth}$ treatment $[\mathrm{j}=\mathrm{CON}$,
$0.75 \mathrm{~g} / \mathrm{kg}$ of $\mathrm{SB}, 1 \mathrm{mg} / \mathrm{kg}$ of $\mathrm{MON}$, or combination (MSB)]; and $\mathrm{E}_{\mathrm{ijkl}}=$ the residual error.

Degrees of freedom were calculated using the Kenward-Roger approximation option of the MIXED procedure. Single df contrasts for CON versus ADD, $\mathrm{SB}$ versus $\mathrm{MON}$, and $\mathrm{ADD}$ versus MSB effects were determined.

For all variables, significant treatment and interaction effects were noted at $P \leq 0.05$ and trends at 0.05 $<P \leq 0.10$. Outliers were removed from the data set if they were $2.5 \mathrm{SD}$ or greater from the mean of each variable.

\section{RESULTS}

The nutrient analysis of the TMR is presented in Table 2. Ingredient composition varied due to changes in the feeds used over the 13-mo period it took to complete the experiment. Dry matter intake, FE, ADG, BW, and skeletal measurements are presented in Table 3 .

During the study, 5 heifers were treated with antibiotics to treat elevated body temperatures (body temperature $>39.17^{\circ} \mathrm{C}$ ). Out of the 5,1 heifer on SB was

Table 3. Intake and performance of heifers fed $0 \mathrm{mg} / \mathrm{kg}$ additive, $0.75 \mathrm{mg} / \mathrm{kg}$ sodium butyrate, $1 \mathrm{mg} / \mathrm{kg}$ monensin, or combined sodium butyrate and monensin, from 12 to 24 wk of age

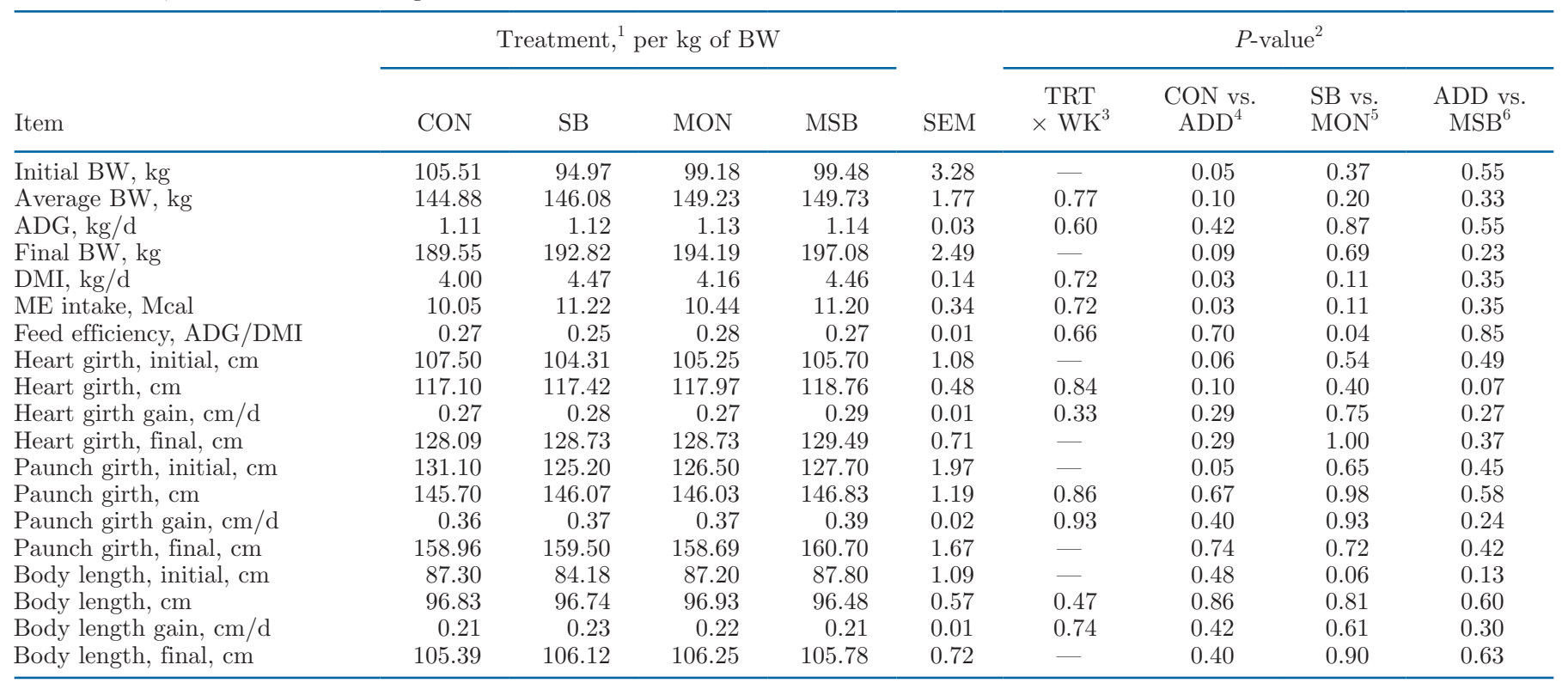

${ }^{1}$ Treatment: $\mathrm{CON}=0 \mathrm{~g} / \mathrm{d}$ of additive; $\mathrm{SB}=0.75 \mathrm{~g}$ of sodium butyrate $/ \mathrm{kg}$ of $\mathrm{BW} ; \mathrm{MON}=1 \mathrm{mg}$ of monensin sodium $/ \mathrm{kg}$ of $\mathrm{BW} ; \mathrm{MSB}=\mathrm{sodium}$ butyrate and monensin sodium.

${ }^{2} P$-value significant if $<0.05$; trend if $<0.10$.

${ }^{3}$ Treatment $\times$ week interaction.

${ }^{4}$ Single df contrast: control vs. additives.

${ }^{5}$ Single df contrast: sodium butyrate vs. monensin sodium.

${ }^{6}$ Single df contrast: single additives vs. combination. 
treated from d 95 to d 97 of age (d 11 to d 13 on study); 2 were from MON, with one treated from d 92 to d 94 of age (d 10 to d 12 on study) and the other from d 90 to d 92 of age (d 6 to d 8 on study); and 2 were from MSB, with one treated from d 97 to d 99 of age (d 13 to d 15 on study) and the other from d 95 to d 97 of age (d 11 to $d 13$ on study). The heifer treated for fever from the SB group was later treated from d 126 to $\mathrm{d}$ 128 of age (d 42 to d 44 on study) for an abscess on her leg. Six heifers on study were treated with amprolium (Corid, Huvepharma, Sofia, Bulgaria) from 113 to 117 d of age (d 29 to d 33 on study) per the university veterinarian and barn standard operating procedures. Out of the 6,2 heifers were from CON, 2 were from SB, and 2 were from MON. All were treated for varying amounts of severity of coccidia. Heifers treated with amprolium were removed from the coccidia statistical analysis for the week following treatment.

Average BW tended $(P=0.10)$ to be greater for heifers fed any ADD compared with CON. Average daily gain was similar for all treatments. Final BW tended $(P=0.09)$ to be greater for heifers fed any ADD compared with CON. Dry matter and ME intake were greater $(P=0.03)$ in heifers fed any ADD compared with CON. Feed efficiency was increased $(P=0.04)$ in heifers supplemented with MON compared with heifers supplemented with SB. For FE, no differences were detected between $\mathrm{CON}$ heifers and those receiving any ADD.

Average heart girth tended $(P=0.10)$ to be greater in heifers fed any ADD compared with CON, and tended $(P=0.07)$ to be greater in heifers fed the MSB diet compared with SB and MON. No differences were detected among all treatments in heart girth gain, final heart girth, average paunch girth, paunch girth gain, final paunch girth, average body length, body length gain, and final body length. Overall gains are presented in Table 4, and all overall measurements (BW, heart girth gain, paunch girth gain, and body length gain) showed no differences among treatments.

Fecal coccidia oocyst counts and blood metabolites are presented in Table 5 . The number of coccidian oocysts present in fecal samples was reduced $(P=0.03)$ in heifers provided any ADD compared with CON. Incidence rate of coccidia was reduced $(P=0.003)$ in heifers provided any ADD compared with CON.

Concentrations of average PUN and final PUN were similar among treatments. Plasma concentrations of glucose were similar between $\mathrm{CON}$ and ADD. However, plasma concentrations of glucose tended $(P=0.09)$ to increase with either SB and MON compared with MSB. We detected no differences in concentrations of final plasma glucose among all treatments. Average ketone concentrations with any ADD resulted in greater $(P=0.002)$ concentrations of ketones compared with CON. An increase was detectable $(P=0.0001)$ in average ketone concentrations in heifers supplemented SB compared with MON, which indicates that SB was consumed and absorbed. Finally, an increase occurred $(P=0.03)$ in average ketone concentrations in MSB heifers compared with SB and MON. Final ketones were similar between $\mathrm{CON}$ and ADD. However, final ketones tended $(P=0.09)$ to be greater in heifers fed SB compared with heifers fed MON. Final ketones were also increased $(P=0.04)$ in MSB heifers compared with SB and MON.

Data collected during the first digestibility measurement period (wk 3) are shown in Table 6. Dry matter intake during the digestibility period was similar between CON and ADD groups. However, DMI during the digestibility period tended $(P=0.10)$ to be greater in heifers fed SB compared with MON, as well as in heifers fed MSB compared with SB and MON. Apparent total-tract digestibility of DM, NDF, ADF,

Table 4. Overall BW and skeletal measurement gains of heifers fed $0 \mathrm{mg} / \mathrm{kg}$ additive, $0.75 \mathrm{mg} / \mathrm{kg}$ sodium butyrate, $1 \mathrm{mg} / \mathrm{kg} \mathrm{monensin}$, or combined sodium butyrate and monensin from 12 to $24 \mathrm{wk}$ of age

\begin{tabular}{|c|c|c|c|c|c|c|c|c|}
\hline \multirow[b]{2}{*}{ Item } & \multicolumn{4}{|c|}{ Treatment, ${ }^{1}$ per $\mathrm{kg}$ of BW } & \multirow[b]{2}{*}{ SEM } & \multicolumn{3}{|c|}{$P$-value ${ }^{2}$} \\
\hline & $\mathrm{CON}$ & SB & MON & MSB & & $\begin{array}{c}\mathrm{CON} \text { vs. } \\
\mathrm{ADD}^{3}\end{array}$ & $\begin{array}{l}\text { SB vs. } \\
\text { MON }^{4}\end{array}$ & $\begin{array}{c}\mathrm{ADD} \text { vs. } \\
\mathrm{MSB}^{5}\end{array}$ \\
\hline Heart girth, cm & 22.30 & 23.12 & 23.06 & 23.80 & 0.67 & 0.20 & 0.95 & 0.39 \\
\hline Paunch girth, cm & 31.34 & 31.87 & 31.06 & 33.08 & 1.67 & 0.74 & 0.72 & 0.42 \\
\hline Body length, cm & 18.77 & 19.51 & 19.63 & 19.16 & 0.72 & 0.39 & 0.91 & 0.63 \\
\hline
\end{tabular}

${ }^{1}$ Treatment: $\mathrm{CON}=0 \mathrm{~g} / \mathrm{d}$ of additive; $\mathrm{SB}=0.75 \mathrm{~g}$ of sodium butyrate $/ \mathrm{kg}$ of $\mathrm{BW} ; \mathrm{MON}=1 \mathrm{mg}$ of monensin sodium $/ \mathrm{kg}$ of $\mathrm{BW} ;$ and $\mathrm{MSB}=$ sodium butyrate and monensin sodium.

${ }^{2} P$-value significant if $<0.05$; trend if $<0.10$.

${ }^{3}$ Single df contrast: control vs. additives.

${ }^{4}$ Single df contrast: sodium butyrate vs. monensin sodium.

${ }^{5}$ Single df contrast: single additives vs. combination. 
Table 5. Coccidia count, plasma glucose, plasma urea nitrogen (PUN), and whole-blood ketones of heifers fed $0 \mathrm{mg} / \mathrm{kg}$ additive, $0.75 \mathrm{mg} / \mathrm{kg}$ sodium butyrate, $1 \mathrm{mg} / \mathrm{kg}$ monensin, or combined sodium butyrate and monensin, from 12 to 24 wk of age

\begin{tabular}{|c|c|c|c|c|c|c|c|c|c|}
\hline \multirow[b]{2}{*}{ Item } & \multicolumn{4}{|c|}{ Treatment, ${ }^{1}$ per $\mathrm{kg}$ of $\mathrm{BW}$} & \multirow[b]{2}{*}{ SEM } & \multicolumn{4}{|c|}{$P$-value ${ }^{2}$} \\
\hline & $\mathrm{CON}$ & SB & $\mathrm{MON}$ & MSB & & $\begin{array}{c}\text { TRT } \\
\times \mathrm{WK}^{3}\end{array}$ & $\begin{array}{c}\text { CON vs. } \\
\mathrm{ADD}^{4}\end{array}$ & $\begin{array}{l}\text { SB vs. } \\
\text { MON }^{5}\end{array}$ & $\begin{array}{c}\text { ADD vs } \\
\text { MSB }^{6}\end{array}$ \\
\hline Initial coccidia $/ \mathrm{kg}$ of feces & 567.0 & $4,567.0$ & 333.0 & $2,930.0$ & 302.5 & - & $<0.0001$ & $<0.0001$ & 0.20 \\
\hline Coccidia $/ \mathrm{kg}$ of feces & $1,265.7$ & 715.1 & 778.4 & 773.7 & 191.9 & 0.90 & 0.03 & 0.82 & 0.91 \\
\hline Coccidiosis incidence rate, ${ }^{7} \%$ & 43.8 & 28.9 & 26.3 & 26.7 & 4.93 & 0.99 & 0.003 & 0.71 & 0.87 \\
\hline Initial PUN, mg/dL & 22.5 & 20.4 & 19.4 & 21.7 & 1.65 & - & 0.31 & 0.66 & 0.40 \\
\hline Initial glucose, $\mathrm{mg} / \mathrm{dL}$ & 81.3 & 81.4 & 86.7 & 76.3 & 2.56 & - & 0.98 & 0.16 & 0.02 \\
\hline Glucose, $\mathrm{mg} / \mathrm{dL}$ & 84.5 & 85.0 & 87.7 & 83.3 & 1.43 & 0.94 & 0.64 & 0.18 & 0.09 \\
\hline Final glucose, mg/dL & 89.8 & 89.1 & 88.7 & 85.6 & 1.95 & - & 0.36 & 0.89 & 0.17 \\
\hline Initial ketones, $\mathrm{mmol} / \mathrm{L}$ & 0.46 & 0.45 & 0.46 & 0.39 & 0.05 & - & 0.72 & 0.97 & 0.29 \\
\hline Ketones, $\mathrm{mmol} / \mathrm{L}$ & 0.44 & 0.50 & 0.44 & 0.50 & 0.01 & 0.77 & 0.002 & 0.0001 & 0.03 \\
\hline Final ketones, mmol/L & 0.46 & 0.50 & 0.44 & 0.54 & 0.02 & - & 0.26 & 0.09 & 0.04 \\
\hline
\end{tabular}

${ }^{1}$ Treatment: $\mathrm{CON}=0 \mathrm{~g} / \mathrm{d}$ of additive; $\mathrm{SB}=0.75 \mathrm{~g}$ of sodium butyrate $/ \mathrm{kg}$ of $\mathrm{BW} ; \mathrm{MON}=1 \mathrm{mg}$ of monensin sodium $/ \mathrm{kg}$ of $\mathrm{BW} ; \mathrm{MSB}=\mathrm{sodium}$ butyrate and monensin sodium.

${ }^{2} P$-value significant if $<0.05$; trend if $<0.10$.

${ }^{3}$ Treatment $\times$ week interaction.

${ }^{4}$ Single df contrast: control vs. additives.

${ }^{5}$ Single df contrast: sodium butyrate vs. monensin sodium.

${ }^{6}$ Single df contrast: single additives vs. combination.

${ }^{7}$ Incidence rate $=$ percent of weeks where coccidia oocysts were present in any heifer.

hemicellulose (NDF - ADF), OM, and fat digestibility showed no differences among treatments. Starch digestibility was similar between $\mathrm{CON}$ and ADD, but was increased $(P=0.03)$ in heifers fed MSB compared with $\mathrm{SB}$ and MON.

Data collected during the second digestibility measurement period (wk 9) are shown in Table 7. Dry matter intake during the digestibility period, along with apparent total-tract digestibility of $\mathrm{DM}, \mathrm{CP}, \mathrm{ADF}$, hemicellulose, starch, OM, and fat digestibility were not different among treatments. Neutral detergent fiber digestibility tended $(P=0.08)$ to be greater in $\mathrm{CON}$ diets compared with any ADD. Results for plasma ketone and glucose concentrations, along with the reduction in coccidian oocysts present in feces, suggesting that heifers consumed their treatments.

Table 6. Apparent total-tract nutrient digestibility (\%), wk 3

\begin{tabular}{|c|c|c|c|c|c|c|c|c|}
\hline \multirow[b]{2}{*}{ Item } & \multicolumn{4}{|c|}{ Treatment, ${ }^{1}$ per $\mathrm{kg}$ of $\mathrm{BW}$} & \multirow[b]{2}{*}{ SEM } & \multicolumn{3}{|c|}{$P$-value ${ }^{2}$} \\
\hline & $\mathrm{CON}$ & SB & MON & MSB & & $\begin{array}{c}\text { CON vs. } \\
\mathrm{ADD}^{3}\end{array}$ & $\begin{array}{l}\text { SB vs. } \\
\text { MON }^{4}\end{array}$ & $\begin{array}{l}\text { ADD vs. } \\
\text { MSB }^{5}\end{array}$ \\
\hline DM & 58.6 & 62.6 & 63.5 & 65.6 & 3.19 & 0.16 & 0.85 & 0.51 \\
\hline $\mathrm{CP}$ & 51.2 & 54.0 & 58.0 & 58.4 & 3.82 & 0.21 & 0.44 & 0.58 \\
\hline Hemicellulose $^{6}$ & 58.9 & 65.6 & 62.8 & 66.4 & 3.78 & 0.16 & 0.61 & 0.63 \\
\hline Starch & 99.2 & 99.0 & 99.1 & 99.4 & 0.12 & 0.83 & 0.65 & 0.03 \\
\hline $\mathrm{OM}$ & 61.0 & 65.0 & 65.7 & 67.5 & 3.06 & 0.17 & 0.87 & 0.57 \\
\hline Fat & 56.5 & 62.9 & 60.1 & 62.2 & 5.23 & 0.38 & 0.69 & 0.92 \\
\hline
\end{tabular}

${ }^{1}$ Treatment: $\mathrm{CON}=0 \mathrm{~g} / \mathrm{d}$ of additive; $\mathrm{SB}=0.75 \mathrm{~g}$ of sodium butyrate $/ \mathrm{kg}$ of $\mathrm{BW} ; \mathrm{MON}=1 \mathrm{mg}$ of monensin sodium $/ \mathrm{kg}$ of $\mathrm{BW} ; \mathrm{MSB}=\mathrm{sodium}$ butyrate and monensin sodium.

${ }^{2} P$-value significant if $<0.05$; trend if $<0.10$.

${ }^{3}$ Single df contrast: control vs. additives.

${ }^{4}$ Single df contrast: sodium butyrate vs. monensin sodium.

${ }^{5}$ Single df contrast: single additives vs. combination.

${ }^{6}$ Hemicellulose $=\mathrm{NDF}-\mathrm{ADF}$. 


\section{DISCUSSION}

In this study, we observed that, compared with CON, the addition of any ADD tended to improve BW. Monensin is approved for growing heifers by the US Food and Drug Administration for improved feed efficiency and increased rate of weight gain (Code of Federal Regulations, 2019). Results of this study for MON are supported by Goodrich et al. (1984), who found that, compared with control diets, feedlot cattle fed diets supplemented with MON gained weight $1.6 \%$ faster, ingested $6.4 \%$ less feed, and required $7.5 \%$ less feed per $100 \mathrm{~kg}$ of gain. In heifers, much of the older research has indicated improved ADG with MON supplementation (Males et al., 1979; Rouquette et al., 1980; Baile et al., 1982). However, research is inconsistent. In bred heifers, Hemphill et al. (2018) found a tendency for BW to increase with MON supplementation, but when $\mathrm{BW}$ was calculated as a change from $\mathrm{d} 0$, significance was no longer present. Those authors surmised that the changes differed enough on d 0 to cause a treatment effect, rather than MON affecting BW. Many studies also indicate that BW and ADG are not improved with ionophore supplementation (Meinert et al., 1992; Benchaar et al., 2005; Mullins et al., 2012; Chapman et al., 2017). Results of this study for SB are supported by Rice et al. (2019), who observed that as SB increased from $0.25 \mathrm{~g} / \mathrm{kg}$ of BW to $0.75 \mathrm{~g} / \mathrm{kg}$ of BW, average BW increased and final BW tended to increase.

An increase was seen in DMI in calves fed any ADD compared with CON. For supplementation with either SB or MON, research does not indicate an increased response in DMI. Typically, research has shown that DMI in MON-supplemented heifers would be decreased (Dyer et al., 1980; Baile et al., 1982; Wood et al., 2016), and Goodrich et al. (1984) demonstrated the same trend in feedlot cattle. However, some studies indicate that DMI is not affected by MON supplementation (Rouquette et al., 1980; Wood et al., 2016; Chapman et al., 2017). Research has shown that DMI in SB-supplemented animals is not affected (Guilloteau et al., 2009; Górka et al., 2014; Kowalski et al., 2015; Rice et al., 2019).

Although an increase in DMI was not generally seen in either SB or MON supplementation, we may be able to attribute the increase in DMI observed in this study to the increased $\mathrm{Na}^{+}$provided in the diet. Mineral ion content in feed has been shown to influence water intake in cattle (Murphy 1992), specifically increasing 50 $\pm 23 \mathrm{~mL}$ in cows and $54 \pm 4 \mathrm{~mL}$ in calves for each additional gram of sodium provided (Murphy et al., 1983). The additional $\mathrm{Na}^{+}$provided leads to an increase in water consumption, which ultimately leads to an increased rate of passage and increased DMI. In calves, it is believed that DMI is related to water intake, because calves require 4 times more water than feed (DM; Quigley et al., 2006; Kertz, 2014; Kononoff et al., 2017). Leibholz et al. (1980) provided 60 male Friesian calves, from 3 to 11 wk of age, with diets supplemented with $\mathrm{NaCl}$ at $0.3,1.1,1.9$, or $2.8 \%$ of the diet content or with $\mathrm{NaHCO}_{3}$ at 1.1 or $1.9 \%$ of the diet content. Feed intake in calves fed 1.1 and $1.9 \% \mathrm{Na}$ from $\mathrm{NaHCO}_{3}$ was 8 and $15 \%$ greater than the feed intake of calves fed $0.3 \% \mathrm{Na}$. Because the calves used by Leibholz et al. (1980) were close in age to the calves used in the current study, we can assume that, among calves, $54 \pm 4 \mathrm{~mL}$ for each additional gram of sodium provided (Murphy et al.,

Table 7. Apparent total-tract nutrient digestibility (\%), wk 9

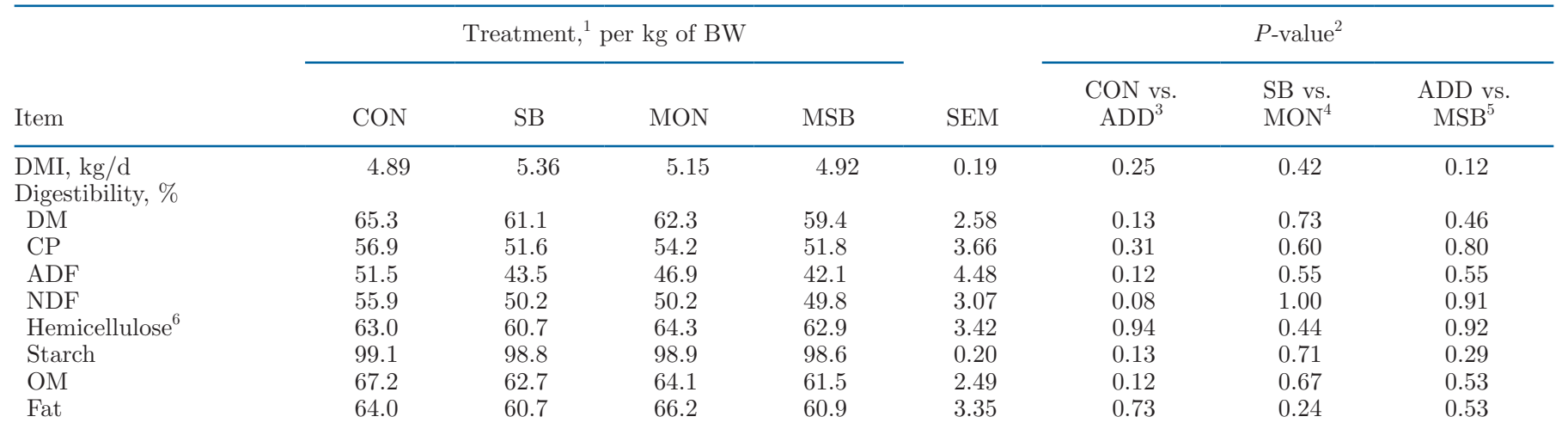

${ }^{1}$ Treatment: $\mathrm{CON}=0 \mathrm{~g} / \mathrm{d}$ of additive; $\mathrm{SB}=0.75 \mathrm{~g}$ of sodium butyrate $/ \mathrm{kg}$ of $\mathrm{BW} ; \mathrm{MON}=1 \mathrm{mg}$ of monensin sodium $/ \mathrm{kg}$ of $\mathrm{BW} ; \mathrm{MSB}=\mathrm{sodium}$ butyrate and monensin sodium.

${ }^{2} P$-value significant if $<0.05$; trend if $<0.10$.

${ }^{3}$ Single df contrast: control vs. additives.

${ }^{4}$ Single df contrast: sodium butyrate vs. monensin sodium.

${ }^{5}$ Single df contrast: single additives vs. combination.

${ }^{6}$ Hemicellulose $=$ NDF - ADF . 
1983) is an appropriate estimate of the resulting water intake and subsequent increase in DMI.

Sodium butyrate drove the increase in DMI and ME intake. For example, initial BW for SB calves averaged $94.97 \mathrm{~kg}$, and final BW averaged $192.82 \mathrm{~kg}$. So, average initial SB $(0.75 \mathrm{~g} / \mathrm{kg}$ of $\mathrm{BW})$ provided to heifers would have been approximately $71.25 \mathrm{~g} / \mathrm{d}$, and average final SB $(0.75 \mathrm{~g} / \mathrm{kg}$ of $\mathrm{BW})$ provided to heifers would have been approximately $144.75 \mathrm{~g} / \mathrm{d}$. Sodium butyrate used in this study was $21 \%$ sodium, so SB provided an additional 15 to $30.4 \mathrm{~g} / \mathrm{d}$ of additional $\mathrm{Na}^{+}$over the duration of the study. Using the amount of additional water $(\mathrm{mL})$ calves would need to consume per gram of $\mathrm{Na}^{+}$(Murphy et al., 1983), heifers on this study would be consuming an additional 808 to $1,641.5 \mathrm{~mL}$ of water. Finally, putting that into perspective with DMI, with the 4:1 water:feed ratio (Kononoff et al., 2017), SB heifers would have consumed 202 to 410.4 additional $\mathrm{g} / \mathrm{d}$ of DM. This calculation is supported by the data for DMI (Table 3), which indicate that SB heifers were consuming 460 to $470 \mathrm{~g}$ more DM compared with CON.

An increase in DMI can also be supported by the FE response. Although the work with MON has not always been consistent, with older studies finding improvements to $\mathrm{FE}$ and newer work not finding such an FE response (Duffield et al., 2012), we saw an improvement in $\mathrm{FE}$ for heifers fed MON compared with SB. In this study, MON-supplemented heifers had $12 \%$ greater FE compared with SB heifers. This improvement in FE could be due to the size of dose fed and the diet fed (Duffield et al., 2012). In a meta-analysis evaluating MON, studies in which corn silage was fed resulted in an increase in FE (Duffield et al., 2012). This could contribute to the FE response seen in this study, because the ingredient composition consisted of approximately $34 \%$ of DM corn silage. For dose, the current US-approved range for MON to result in an FE response is 6 to $49 \mathrm{mg} / \mathrm{kg}$ of DM. In this study, the average dose for heifers on the MON treatment was $36.76 \pm 6.06 \mathrm{mg}$ of $\mathrm{MON} / \mathrm{kg}$ of $\mathrm{DM}$, which was within the approved US dose range.

In addition to growth benefits, SB and MON have also been shown to affect the overall health of the animal through prevention of coccidiosis. We saw that, compared with CON, any ADD resulted in reduction of coccidian oocysts and of incidence rates of coccidian oocysts present in the feces.

Monensin is a recognized anticoccidial, and the responses seen in this study are supported by the modes of action of MON to specifically target the Eimeria protozoa (Chapman et al., 2010). Monensin affects the sporozoite step of the coccidian lifecycle, causing an increase in available $\mathrm{Na}^{+}$ions to stimulate $\mathrm{Na}^{+}-\mathrm{K}^{+}-$
ATPase to pump excess $\mathrm{Na}^{+}$ions out of the sporozoite (Smith and Galloway, 1983). Monensin can also affect the merozoite step of the coccidian lifecycle, in which merozoites rupture their host sporozoite and encounter the drug (Mehlhorn et al., 1983). With this mode of action in mind, daily feeding of MON is necessary for a continued health response.

The reduction of coccidian oocysts in response to SB supplementation is supported by Rice et al. (2019). Those researchers fed $0,0.25,0.5$, and $0.75 \mathrm{~g} / \mathrm{kg}$ of BW of SB in the diets of heifers after weaning and found a positive quadratic effect of SB on reducing the prevalence of coccidian oocysts in the feces (Rice et al., 2019). However, a few inferences can be hypothesized as to how this response was seen. Because SB contains approximately $21 \% \mathrm{Na}^{+}$and the SB product used in this study was unprotected, $\mathrm{Na}^{+}$will dissociate from butyrate in the rumen and pass to the lower gastrointestinal tract (Górka et al., 2018a). The response observed in the study by Rice and colleagues could be due to a disruption of $\mathrm{Na}^{+}-\mathrm{K}^{+}$-ATPase to pump excess $\mathrm{Na}^{+}$ions out of the sporozoite (Smith and Galloway, 1983). However, using a microencapsulated SB product reduces release of $\mathrm{SB}$ in the rumen, resulting in passage to the intestine (Kowalski et al., 2015; Górka et al., 2018a). Once in the SI, $\mathrm{Na}^{+}$will dissociate from butyrate and potentially disrupt $\mathrm{Na}^{+}-\mathrm{K}^{+}$-ATPase.

Coccidiosis is known to cause intestinal inflammation and damage to the mucosal layer (Guilloteau et al., 2010a). However, because SB is soluble, some unprotected SB can flow with the fluid phase out of the rumen to aid in repairing the SI. About $15 \%$ of ruminal short-chain fatty acid will flow to the omasum, abomasum, and SI (Górka et al., 2018b,c). Butyrate can then be absorbed by the omasum (Rupp et al., 1994; Górka et al., 2018c) or SI (Górka et al., 2018b). Górka et al. (2011b) found that calves supplemented with unprotected SB in TMR had increased mitotic indices and decreased apoptotic indices. In sheep, Górka et al. (2018b) observed a lower mitotic-apoptotic ratio in the SI, but that was due to high amounts of exogenous SB supplemented that may have induced apoptosis. Supplementing SB will cause an increase in cell proliferation (elevated mitotic indices), but that proliferation is typically followed by apoptosis (Górka et al., 2018b). Elevated mitotic indices of intestinal epithelial cells are indicative of an increase in cell proliferation, which provides the intestinal mucosa the ability to rapidly mature and heal after injury related to scours (Guilloteau et al., 2010a). Sodium butyrate could heal the intestinal mucosa, which would reduce inflammation of these tissues. In repairing epithelial tissue from damage due to scours, second-generation merozoites could be removed before sexual reproduction. 
This study detected no effect of treatment on PUN concentration in heifers. This was also observed by Rice et al. (2019) for SB and by Chapman et al. (2017) for MON. A tendency to decrease plasma glucose was seen in MSB compared with SB and MON. Monensinsupplemented heifers expressed the greatest $(87.7 \mathrm{mg} /$ dL) average plasma glucose concentration. Monensin supplementation results in a decrease in gram-positive bacteria in the rumen, which will lower the concentration of acetate and butyrate, the 2 non-glucogenic VFA (McDougall et al., 2004; Ellis et al., 2012). Gramnegative bacteria have a thicker cell membrane, which makes them less susceptible to ionophore-caused cell destruction (Callaway et al., 2003), thus resulting in an increase. When gram-negative bacteria thrive, glucogenic propionate will increase (Ellis et al., 2012). Ruminal propionate uptake is converted into glucose in the liver. Thus, supplementing MON increases ruminal propionate, which will increase available propionate for hepatic conversion, to increase circulating glucose concentrations. Heifers supplemented with SB expressed lower average glucose concentrations compared with MON. Aiello et al. (1989) incorporated $2.5 \mathrm{~m} M$ propionate into glucose in the presence of either $0,1.25$, or $2.5 \mathrm{~m} M$ butyrate. They found that butyrate inhibited propionate metabolism. The inhibition of propionate metabolism would mean less is available for conversion to glucose in the liver, resulting in slightly decreased average plasma glucose concentrations in SB heifers and the trend of MSB having the lowest average plasma glucose concentration. Additionally, between pre-ruminant to ruminant digestion, there is a shift of absorption from glucose in the intestine to gluconeogenesis in the liver (Baldwin et al., 2004). Due to this increase in hepatic enzyme activity, as fermentation becomes more important for the heifer, less carbohydrate is available for postruminal digestion, resulting in decreased absorption of glucose (Rice et al., 2019). Alternatively, gluconeogenesis may be altered through the infusion or supplementation of butyrate. In sheep, Sano et al. (1995) observed an increase in plasma insulin with intravenous butyrate infusion, along with a reduction in plasma glucose after infusion. In lactating dairy cows, Herrick et al. (2017) observed an increase in insulin secretion with SB supplementation; thus butyrate indirectly lowered plasma glucose.

Average ketone concentrations increased in any ADD versus $\mathrm{CON}$, in $\mathrm{SB}$ compared with $\mathrm{MON}$, and in $\mathrm{MSB}$ versus the average of $\mathrm{SB}$ and $\mathrm{MON}$. These results are supported by data indicating that rumen epithelium rapidly converts butyrate to ketone bodies through alimentary ketogenesis (Holtenius and Holtenius, 1996; Müller et al., 2002; Herrick et al., 2017; Rice et al., 2019).
In the wk-3 digestibility period, DMI tended to be higher in heifers fed SB compared with MON, as well as in heifers fed MSB compared with SB and MON. We attribute the increase in DMI to the increased $\mathrm{Na}^{+}$ provided in the diet (Murphy et al., 1983). During wk 3 , heifers supplemented SB (SB and MSB) had an average $\mathrm{BW}$ of $115.8 \pm 10.04 \mathrm{~kg}$, and $\mathrm{SB}$ provided to heifers during this time $(0.75 \mathrm{~g} / \mathrm{kg}$ of BW) was on average $86.87 \pm 7.53 \mathrm{~g}$. Based on our earlier calculations, SB-supplemented heifers (SB and MSB) would have consumed 222.5 to $267.5 \mathrm{~g} / \mathrm{d}$ of additional DM. Sodium butyrate-supplemented heifers during the wk-3 digestibility phase consumed approximately $440 \mathrm{~g} / \mathrm{d}$ of DM more than MON. Along with increased water consumption, SB supplementation has been shown to increase pancreatic juice secretion, with a $40 \%$ increase in lipase production and a $52 \%$ increase in chymotrypsin production (Guilloteau et al., 2010a). Both water intake and improvement in SI digestibility will ultimately lead to an increased rate of passage and increase in DMI. This may also explain the increase in starch digestibility seen in MSB heifers compared with SB and MON. However, differences in starch digestibility were small.

In the wk-9 digestibility period, NDF tended to be increased in CON diets compared with any ADD. For MON, our results do not concur with research that indicates no effect of ionophores on fiber digestibility (McGuffey, 2017). For SB, our results are supported by research that indicates a decrease in fiber digestibility in the rumen of sheep (Górka et al., 2017; Górka et al., 2018b,c). However, Ren et al. (2018) observed an increase in NDF digestibility in sheep supplemented with tributyrin, whereas Rice et al. (2019) observed no difference in fiber digestibility in heifers supplemented with unprotected SB.

Because butyrate is the primary VFA utilized by the rumen epithelial tissue, it will be absorbed in the rumen and used to improve the dimensions and density of papillae. Improvements in papillae result in an increase in surface area for absorption of feed, thus allowing the heifer to more effectively utilize nutrients and optimize BW and skeletal growth gains. As seen in numerous studies, some SB can pass into the lower gastrointestinal tract (Górka et al., 2018b,c) and improve the dimensions and density of intestinal villi (Guilloteau et al., 2009; Górka et al., 2014, 2018b), along with improving and repairing the mucosal layer (Guilloteau et al., 2010a). The results from this study confirm that ADD supplementation in feed can improve BW gain. In general, ADD supplementation tended to increase average and final BW. This study, and the work that preceded it (Rice et al., 2019), were the first instances to see the prevention of coccidiosis with SB supplementation. Specifically pertaining to the lower gastro- 
intestinal tract, supplementation with ADD here has been shown to increase the health of the animal, either by possibly repairing epithelial tissue or by directly affecting resident coccidia. Further research is needed to understand how SB affects coccidia.

\section{ACKNOWLEDGMENTS}

The authors thank Adisseo USA Inc. (Alpharetta, GA) for supporting this project. We also thank the staff at the Fairchild Dairy Teaching and Research Center and the undergraduate students of the University of New Hampshire (Durham) who helped with sampling and laboratory work. Partial funding was provided by the New Hampshire Agricultural Experiment Station (Durham). This is scientific contribution number 2853. This work was supported by the USDA National Institute of Food and Agriculture project (Hatch Multistate NC2042; Acession number 10012830; Washington, DC). The authors declare that they have no conflicts of interest.

\section{REFERENCES}

Aiello, R. J., L. E. Armentano, S. J. Bertics, and A. T. Murphy. 1989. Volatile fatty acid uptake and propionate metabolism in ruminant hepatocytes. J. Dairy Sci. 72:942-949. https://doi.org/10.3168/jds .S0022-0302(89)79187-6.

AOAC International. 1998. Official Methods of Analysis. 16th ed. AOAC International, Arlington, VA.

AOAC International. 2006. Official Methods of Analysis. 18th ed. AOAC International, Gaithersburg, MD.

Baile, C. A., C. L. McLaughlin, W. V. Chalupa, D. L. Snyder, L. C. Pendlum, and E. L. Potter. 1982. Effects of monensin fed to replacement dairy heifers during the growing and gestation period upon growth, reproduction, and subsequent lactation. J. Dairy Sci. 65:1941-1944. https://doi.org/10.3168/jds.S0022-0302(82)82442 -9 .

Baldwin, R. L. IV, K. R. McLeod, J. L. Klotz, and R. N. Heitmann. 2004. Rumen development, intestinal growth, and hepatic metabolism in the pre- and postweaning ruminant. J. Dairy Sci. 87(Suppl.):E55-E65. https://doi.org/10.3168/jds.S0022 -0302(04)70061-2.

Benchaar, C., J. L. Duynisveld, and E. Charmley. 2005. Effects of monensin and increasing dose levels of a mixture of essential oil compounds on intake, digestion and growth performance of beef cattle. Can. J. Anim. Sci. 86:91-96.

Bliss, D. H., and W. G. Kvasnicka. 1997. The fecal examination: A missing link in food animal practice. Compend. Contin. Educ. Pract. Vet. 19:S104-S109.

Callaway, T. R., T. S. Edrington, J. L. Rychlik, K. J. Genovese, T. L. Poole, Y. S. Jung, K. M. Bischoff, R. C. Anderson, and D. J. Nisbet. 2003. Ionophores: Their use as ruminant growth promotants and impact on food safety. Curr. Issues Intest. Microbiol. 4:43-51.

Chapman, C. E., H. Chester-Jones, D. Ziegler, J. A. Clapper, and P. S. Erickson. 2017. Effects of cinnamaldehyde or monensin on performance of weaned Holstein dairy heifers. J. Dairy Sci. 100:17121719. https://doi.org/10.3168/jds.2016-11893.

Chapman, H. D., T. K. Jeffers, and R. B. Williams. 2010. Forty years of monensin for the control of coccidiosis in poultry. Poult. Sci. 89:1788-1801. https://doi.org/10.3382/ps.2010-00931.

Code of Federal Regulations. 2019. Title 21: Food and Drugs. Subchapter E-Animal drugs, feeds, and related products. Accessed
May 2020. https://www.accessdata.fda.gov/scripts/cdrh/cfdocs/ cfcfr $/$ CFRSearch.cfm?fr $=558.355$.

Deelen, S. M., K. E. Leslie, M. A. Steele, E. Eckert, H. E. Brown, and T. J. DeVries. 2016. Validation of a calf-side $\beta$-hydroxybutyrate test and its utility for estimation of starter intake in dairy calves around weaning. J. Dairy Sci. 99:7624-7633. https://doi.org/10 .3168/jds.2016-11097.

Duffield, T. F., J. K. Merrill, and R. N. Bagg. 2012. Meta-analysis of the effects of monensin in beef cattle on feed efficiency, body weight gain, and dry matter intake. J. Anim. Sci. 90:4583-4592. https://doi.org/10.2527/jas.2011-5018.

Dyer, I. A., R. M. Koes, M. L. Herlugson, L. Bola Ojikutu, R. L. Preston, P. Zimmer, and R. DeLay. 1980. Effect of avoparcin and monensin on performance of finishing heifers. J. Anim. Sci. 51:843-846. https://doi.org/10.2527/jas1980.514843x.

Ellis, J. L., J. Dijkstra, A. Bannink, E. Kebreab, S. E. Hook, S. Archibeque, and J. France. 2012. Quantifying the effect of monensin dose on the rumen volatile fatty acid profile in high grain-fed beef cattle. J. Anim. Sci. 90:2717-2726. https://doi.org/10.2527/jas 2011-3966.

European Commission. 2005. Ban on antibiotics as growth promoters in animal feed enters into effect. Updated Dec. 22, 2005. Accessed Nov. 2019. https://ec.europa.eu/commission/presscorner/detail/ en/IP_05_1687.

Gabler, M. T., P. R. Tozer, and A. J. Heinrichs. 2000. Development of a cost analysis spreadsheet for calculating the costs to raise a replacement dairy heifer. J. Dairy Sci. 83:1104-1109. https://doi .org/10.3168/jds.S0022-0302(00)74975-7.

Goodrich, R. D., J. E. Garrett, D. R. Gast, M. A. Kirick, D. A. Larson, and J. C. Meiske. 1984. Influence of monensin on the performance of cattle. J. Anim. Sci. 58:1484-1498. https://doi.org/10 $.2527 /$ jas $1984.5861484 \mathrm{x}$

Górka, P., Z. M. Kowalski, P. Pietrzak, A. Kotunia, W. Jagusiak, J. J. Holst, P. Guilloteau, and R. Zabielski. 2011a. Effect of method of delivery of sodium butyrate on rumen development in newborn calves. J. Dairy Sci. 94:5578-5588. https://doi.org/10.3168/jds 2011-4166.

Górka, P., Z. M. Kowalski, P. Pietrzak, A. Kotunia, W. Jagusiak, and R. Zabielski. 2011b. Is rumen development in newborn calves affected by different liquid feeds and small intestine development? J. Dairy Sci. 94:3002-3013. https://doi.org/10.3168/jds.2010-3499.

Górka, P., Z. M. Kowalski, R. Zabielski, and P. Guilloteau. 2018a. Invited review: Use of butyrate to promote gastrointestinal tract development in calves. J. Dairy Sci. 101:4785-4800. https://doi .org/10.3168/jds.2017-14086.

Górka, P., P. Pietrzak, A. Kotunia, R. Zabielski, and Z. M. Kowalski. 2014. Effect of method of delivery of sodium butyrate on maturation of the small intestine in newborn calves. J. Dairy Sci. 97:1026-1035. https://doi.org/10.3168/jds.2013-7251.

Górka, P., B. Śliwiński, J. Flaga, J. Olszewski, P. Nawrocka, K. Sobkowiak, R. Miltko, M. M. Godlewski, R. Zabielski, and Z. M. Kowalski. 2018b. Effect of exogenous butyrate on the gastrointestinal tract of sheep. II. Hydrolytic activity in the rumen and structure and function of the small intestine. J. Anim. Sci. 96:5325-5335. https://doi.org/10.1093/jas/sky368.

Górka, P., B. Śliwiński, J. Flaga, J. Olszewski, M. Wojciechowski, K. Krupa, M. M. Godlewski, R. Zabielski, and Z. M. Kowalski. 2018c. Effect of exogenous butyrate on the gastrointestinal tract of sheep. I. Structure and function of the rumen, omasum, and abomasum. J. Anim. Sci. 96:5311-5324. https://doi.org/10.1093/jas/sky367.

Górka, P., B. Śliwiński, J. Flaga, J. Wieczorek, M. M. Godlewski, E. Wierzchaoś, R. Zabielski, and Z. M. Kowalski. 2017. Effect of butyrate infusion into the rumen on butyrate flow to the duodenum, selected gene expression in the duodenum epithelium, and nutrient digestion in sheep. J. Anim. Sci. 95:2144-2155.

Guilloteau, P., L. Martin, V. Eeckhaut, R. Ducatelle, R. Zabielski, and F. Van Immerseel. 2010a. From the gut to peripheral tissues: the multiple effects of butyrate. Nutr. Res. Rev. 23:366-384. https:// doi.org/10.1017/S0954422410000247.

Guilloteau, P., G. Savary, Y. Jaguelin-Peyrault, V. Romé, L. Le Normand, and R. Zabielski. 2010b. Dietary sodium butyrate supple- 
mentation increases digestibility and pancreatic secretion in young milk-fed calves. J. Dairy Sci. 93:5842-5850. https://doi.org/10 $.3168 /$ jds.2009-2751.

Guilloteau, P., R. Zabielski, J. C. David, J. W. Blum, J. A. Morisset, M. Biernat, J. Woliński, D. Laubitz, and Y. Hamon. 2009. Sodium butyrate as a growth promoter in milk replacer formula for young calves. J. Dairy Sci. 92:1038-1049. https://doi.org/10 $.3168 /$ jds.2008-1213.

Heinrichs, A. J., C. M. Jones, S. M. Gray, P. A. Heinrichs, S. A. Cornelisse, and R. C. Goodling. 2013. Identifying efficient dairy heifer producers using production costs and data envelopment analysis. J. Dairy Sci. 96:7355-7362. https://doi.org/10.3168/jds.2012-6488.

Hemphill, C. N., T. A. Wickersham, J. E. Sawyer, T. M. BrownBrandl, H. C. Freetly, and K. E. Hales. 2018. Effects of feeding monensin to bred heifers fed in a drylot on nutrient and energy balance. J. Anim. Sci. 96:1171-1180. https://doi.org/10.1093/jas/ skx030.

Herrick, K. J., A. R. Hippen, K. F. Kalscheur, D. J. Schingoethe, D. P. Casper, S. C. Moreland, and J. E. van Eys. 2017. Singledose infusion of sodium butyrate, but not lactose, increases plasma $\beta$-hydroxybutyrate and insulin in lactating dairy cows. J. Dairy Sci. 100:757-768. https://doi.org/10.3168/jds.2016-11634.

Holtenius, P., and K. Holtenius. 1996. New aspects of ketone bodies in energy metabolism of dairy cows: A review. Zentralbl. Veterinarmed. A 43:579-587.

Kertz, A. 2014. How much water should dairy calves drink? Feedstuffs 86. http://feedstuffs.com/story-how-much-water-should-dairy -calves-drink-54-109688.

Kononoff, P. J., D. D. Snow, and D. A. Christensen. 2017. Drinking water for dairy cattle. In Large Dairy Herd Management. 3rd ed. American Dairy Science Association, Champaign, IL.

Kowalski, Z. M., P. Górka, J. Flaga, A. Barteczko, K. Burakowska, J. Oprzadek, and R. Zabielski. 2015. Effect of microencapsulated sodium butyrate in the close-up diet on performance of dairy cows in the early lactation period. J. Dairy Sci. 98:3284-3291. https:// doi.org/10.3168/jds.2014-8688.

Leibholz, J., R. C. Kellaway, and G. T. Hargreave. 1980. Effects of sodium chloride and sodium bicarbonate in the diet on the performance of calves. Anim. Feed Sci. Technol. 5:309-314. https://doi .org/10.1016/0377-8401(80)90018-8.

Males, J. R., C. W. Hunt, and D. D. Lee Jr.. 1979. Monensin supplemented winter pasture for growing feeder calves. J. Anim. Sci. 48:1295-1298. https://doi.org/10.2527/jas1979.4861295x.

McDougall, S., L. Young, and F. M. Anniss. 2004. Production and health of pasture-fed dairy cattle following oral treatment with the ionophore lasalocid. J. Dairy Sci. 87:2967-2976. https://doi.org/10 .3168/jds.S0022-0302(04)73428-1.

McGuffey, R. K. 2017. A 100-year review: Metabolic modifiers in dairy cattle nutrition. J. Dairy Sci. 100:10113-10142. https://doi.org/10 .3168/jds.2017-12987.

Mehlhorn, H., H. Pooch, and W. Raether. 1983. The action of polyether ionophorous antibiotics (monensin, salinomycin, lasalocid) on developmental stages of Eimeria tenella (Coccidia, Sporozoa) in vivo and in vitro: Study by light and electron microscopy. Z . Parasitenkd. 69:457-471. https://doi.org/10.1007/BF00927702.

Meinert, R. A., C.-M. J. Yang, A. J. Heinrichs, and G. A. Varga. 1992. Effect of monensin on growth, reproductive performance, and estimated body composition in Holstein heifers. J. Dairy Sci. 75:257-261. https://doi.org/10.3168/jds.S0022-0302(92)77760-1.

Müller, F., K. Huber, H. Pfannkuche, J. R. Aschenbach, G. Breves, and G. Gabel. 2002. Transport of ketone bodies and lactate in the sheep ruminal epithelium by monocarboxylate transporter. Am. J. Physiol. Gastrointest. Liver Physiol. 283:G1139-G1146. https:// doi.org/10.1152/ajpgi.00268.2001

Mullins, C. R., L. K. Mamedova, M. J. Brouk, C. E. Moore, H. B. Green, K. L. Perfield, J. F. Smith, J. P. Harner, and B. J. Bradford. 2012. Effects of monensin on metabolic parameters, feeding behavior, and productivity of transition dairy cows. J. Dairy Sci. 95:1323-1336. https://doi.org/10.3168/jds.2011-4744.
Murphy, M. R. 1992. Water metabolism of dairy cattle. J. Dairy Sci. 75:326-333. https://doi.org/10.3168/jds.S0022-0302(92)77768-6.

Murphy, M. R., C. L. Davis, and G. C. McCoy. 1983. Factors affecting water consumption by Holstein cows in early lactation. J. Dairy Sci. 66:35-38. https://doi.org/10.3168/jds.S0022-0302(83)81750-0. National Research Council. 2001. Nutrient Requirements of Dairy Cattle. 7th rev. ed. National Academy of Sciences, Washington, DC.

Quigley, J. D. III, J. J. Drewry, L. M. Murray, and S. J. Ivey. 1997. Effects of lasalocid in milk replacer or calf starter on health and performance of calves challenged with Eimeria species. J. Dairy Sci 80:2972-2976. https://doi.org/10.3168/jds.S0022-0302(97)76263 -5 .

Quigley, J. D. III, T. A. Wolfe, and T. H. Elsasser. 2006. Effects of additional milk replacer feeding on calf health, growth, and selected blood metabolites in calves. J. Dairy Sci. 89:207-216. https://doi .org/10.3168/jds.S0022-0302(06)72085-9.

Ren, Q. C., J. J. Xuan, L. K. Wang, Q. W. Zhan, D. Z. Yin, Z. Z. Hu, H. J. Yang, W. Zhang, and L. S. Jiang. 2018. Effects of tributyrin supplementation on ruminal microbial protein yield, fermentation characteristics and nutrients degradability in adult Small Tail ewes. Anim. Sci. J. 89:1271-1279. https://doi.org/10.1111/ asj.13033.

Rice, E. M., K. M. Aragona, S. C. Moreland, and P. S. Erickson. 2019. Supplementation of sodium butyrate to postweaned heifer diets: Effects on growth performance, nutrient digestibility, and health. J. Dairy Sci. 102:3121-3130. https://doi.org/10.3168/jds 2018-15525.

Rouquette, F. M. Jr., J. L. Griffin, R. D. Randel, and L. H. Carroll. 1980. Effect of monensin on gain and forage utilization by calves grazing bermudagrass. J. Anim. Sci. 51:521-525. https://doi.org/ 10.2527/jas1980.513521x.

Rupp, G. P., K. K. Kreikemeier, L. J. Perino, and G. S. Ross. 1994. Measurement of volatile fatty acid disappearance and fluid flux across the abomasum of cattle, using an improved omasal cannulation technique. Am. J. Vet. Res. 55:522-529.

Russell, J. B., and H. J. Strobel. 1988. Effects of additives on in vitro ruminal fermentation: A comparison of monensin and bacitracin, another gram-positive antibiotic. J. Anim. Sci. 66:552-558. https: //doi.org/10.2527/jas1988.662552x.

Sano, H., S. Tano, H. Takahashi, and Y. Terashima. 1995. Dose response of plasma insulin and glucagon to intravenous n-butyrate infusion in sheep. J. Anim. Sci. 73:3038-3043. https://doi.org/10 $.2527 / 1995.73103038 x$.

Smith, C. K. Jr., and R. B. Galloway. 1983. Influence of monensin on cation influx and glycolysis of Eimeria tenella sporozoites in vitro. J. Parasitol. 69:666-670. https://doi.org/10.2307/3281137.

Van Keulen, J., and B. A. Young. 1977. Evaluation of acid-insoluble ash as a natural marker in ruminant digestibility studies. J. Anim. Sci. 44:282-287. https://doi.org/10.2527/jas1977.442282x.

Van Soest, P. J., J. B. Robertson, and B. A. Lewis. 1991. Carbohydrate methodology, metabolism, and nutritional implications in dairy cattle: Methods for dietary fiber, neutral detergent fiber, and nonstarch polysaccharides in relation to animal nutrition. J. Dairy Sci. 74:3583-3597. https://doi.org/10.3168/jds.S0022 $-0302(91) 78551-2$.

Wood, K. M., A. C. J. Pinto, D. D. Millen, R. Kanafany Guzman, and G. B. Penner. 2016. The effect of monensin concentration on dry matter intake, ruminal fermentation, short-chain fatty acid absorption, total tract digestibility, and total gastrointestinal barrier function in beef heifers. J. Anim. Sci. 94:2471-2478. https:// doi.org/10.2527/jas.2016-0356.

\section{ORCIDS}

T. C. Stahl ๑ https://orcid.org/0000-0002-5025-854X

K. D. Klanderman (ㄴ) https://orcid.org/0000-0002-7669-936X

P. S. Erickson () https://orcid.org/0000-0002-8028-3279 